\title{
Deformation and metamorphism of gold-sulphide lodes in the Bhukia-Jagpura gold prospect, Rajasthan: Implications for ore genesis
}

\author{
S Deol*, A Chattopadhyay and M Deb \\ Department of Geology, University of Delhi, Delhi 110 00\%, India. \\ *Corresponding author. e-mail: swatideol@yahoo.com
}

The role of polyphase deformation in controlling the emplacement of gold-quartz lodes in dilational regimes is demonstrated from the Proterozoic Bhukia-Jagpura gold prospect in south Rajasthan. Earlier researchers deciphered the gold-sulphide mineralisation event as synchronous to the second phase of deformation $\left(\mathrm{D}_{2}\right)$ without convincing microstructural or metamorphic evidences. In this contribution, we correlate the deformation and metamorphic imprints in the host rocks with those in the gold-sulphide mineralised zone, and present a new interpretation for the relative timing of gold emplacement vis-àvis deformation. The ore-forming process first involved layer-parallel influx of ore-bearing hydrothermal fluids along $\mathrm{S}_{1}$ schistosity in the host rocks, synkinematic with respect to the first phase of deformation $\left(\mathrm{D}_{1}\right)$. This initial ore concentration experienced metamorphism isofacially $\left(\sim 500^{\circ} \mathrm{C}\right.$ at $\left.5.3 \mathrm{~kb}\right)$ along with its host rocks during $\mathrm{D}_{1}$, and subsequently underwent extensive remobilisation, giving rise to gold-bearing silicified lodes along the hinges and axial surfaces of $\mathrm{F}_{2}$ folds during $\mathrm{D}_{2}$.

\section{Introduction}

In terrains with lode gold deposits, structures produced during regional deformation, especially faults/shear zones, etc., play an important role in localisation of gold by controlling the flow of the ore fluid and precipitation of the metal. Deformation and metamorphic signatures of the host rocks of gold-sulphide ores in turn help to correlate ore genesis and its emplacement with regional (and/or local) tectonothermal events. Important examples of such studies worldwide include Hill End gold field, Australia (Windh 1995); Meguma gold deposit, Nova Scotia, Canada (Horne and Culshaw 2001; Kontak and Horne 2010) and Sigma Mine, Val d'Or, Quebec (Robert and Poulsen 2001), amongst others. In Indian gold deposits, focused study on this aspect is relatively less, except in parts of Dharwar Craton (Kolar, Hutti and Ajjanhalli), where genetic relationships between structural elements and gold have been studied (Ziauddin and Ramachandra 1963; Kolb et al. 2004a, b, 2005). Chattopadhyay (2010) has recently reviewed the structural characteristics of orogenic gold deposits, with special reference to Indian gold deposits, and had pointed out the need for further research in this area.

The present contribution is an attempt to analyse the influence of deformation and metamorphism on the Proterozoic lode gold-type mineralisation ( $c f$. Partington and Williams 2000) in Bhukia-Jagpura area (lat.: $23^{\circ} 52^{\prime}$; long.: $74^{\circ} 21^{\prime}$ ), Banswara district, south Rajasthan. The goldsulphide mineralisation in Bhukia area has been intensively explored since their discovery (Grover and Verma 1993). However, the relative timing and

Keywords. Gold-sulphide mineralisation; structural control; ore metamorphism; remobilisation. 
mode of emplacement of quartz-gold lodes have remained a matter of debate. Garhia et al. (2001) have suggested that sulphide-hosted gold mineralisation and associated hydrothermally altered zones characterised by intense carbonatisation, amphibolitisation and tourmalinitisation formed synchronous with early to late $\mathrm{F}_{2}$ deformation. However, the detailed field and microstructural observations recorded in the present paper do not support this inference. Moreover, the detailed microstructural study of ore and host rocks, which is key to understand the effect of deformation on movement of ore-bearing fluids, were not dealt with in the earlier work mentioned above. The present work examines the relationship between deformation, metamorphism and gold-bearing sulphide mineralisation in the area from a holistic approach, and reinterprets the relative timing of ore emplacement in the context of the regional tectonothermal events. This also enhances our general understanding of the genesis of a structurally controlled gold-sulphide mineralisation.

\section{Geological setting of Bhukia-Jagpura prospect}

The Bhukia-Jagpura is located in the extreme southeastern part of Aravalli-Delhi Orogenic Belt (ADOB) (figure 1). The geology of ADOB comprises an Archean basement, the Banded Gneissic Complex (BGC), overlain by Proterozoic cover sequences (Gupta 1934; Heron 1953). In the Udaipur region, the Paleoproterozoic succession of the Aravalli-Jharol belt constitutes the type Aravalli Supergroup of rocks (figure 1). The lowermost part of the Aravalli Supergroup, lying close to its contact with the BGC, hosts the goldsulfide mineralisation in Bhukia-Jagpura area. Sinha-Roy (1996) named this lowermost sequence as Delwara Group and subdivided it into a lower Jakham Formation and an upper Bhukia Formation. The Bhukia Formation, that hosts the gold-sulphide mineralisation, mainly comprises a carbonate sequence along with pelites and quartzites (inset in figure 1). Roy and Jakhar (2002), on the other hand, considered the lithology of Bhukia-Jagpura area to be the southeastern extension of the Jhamarkotra Formation of the lower Aravalli Group overlying the lowermost Delwara Formation. $\mathrm{A} \mathrm{Pb}-\mathrm{Pb}$ model age of galena separated from barite lenses in the Negaria volcanics was between 2150 and $2075 \mathrm{Ma}$ (Deb and Thorpe 2004), and is the best age constraint available so far for the basal Aravalli mafic volcanic rocks of the Delwara Formation. U-Pb zircon and titanite analyses from quartz-albite rocks from the Bhukia mineralised zone gave an age estimate between $\sim 1820$ and $\sim 1740 \mathrm{Ma}$ (Deb and Thorpe, unpubl. data).

Dolomitic marble, well bedded calc-silicate rocks, and meta-pelites (garnet-staurolitealuminosilicate-bearing mica schist), constitute the lithology of Bhukia-Jagpura area, along with some finely laminated tuffaceous units, tourmalinebearing rocks, bedded albite-bearing rocks, and scarce quartzite and carbon phyllite. Scanty exposures of amphibolites and meta-ironstones are also present. The rocks in the area are intruded by a number of pegmatitic and granitic bodies. Within this lithologic package, the gold-sulphide mineralisation is associated with dolomitic marble, calc-silicate rocks, tuffaceous quartz-albite rocks, albite-rich rocks and tourmaline-bearing rocks.

Sengupta (1976) described three generations of folding (figure 2a), of which the second generation folds $\left(\mathrm{F}_{2}\right)$ control the regional structural pattern. Later Garhia et al. (2001) described the first folds (their $\mathrm{AF}_{1}$ ) as reclined with high amplitude/ wavelength ratio, and a penetrative $\mathrm{S}_{1}$ schistosity parallel to the bedding $\left(\mathrm{S}_{0}\right)$. This schistosity is the form surface of the second generation $\left(\mathrm{AF}_{2}\right)$ asymmetric to overturned, doubly plunging folds controlling the regional map pattern, with $\mathrm{N}-\mathrm{S}$ to NNW-SSE striking $\mathrm{S}_{2}$ schistosity. $\mathrm{F}_{3}$ has been described as broad open warps with widely spaced fracture cleavage. A major NNW-SSE striking dislocation zone (Ghatol thrust) has been described from this area, which formed between the $\mathrm{F}_{2}$ and $\mathrm{F}_{3}$ folding (Garhia et al. 2001). Mineralogical and genetic studies on this prospect have been carried out by Guha (2004) who suggested that "the sulphide-Au mineralisation was, in part, syn- to post depositional to the host rocks, and were metamorphosed later". Golani et al. $(1999,2002)$ suggested that mantle carbon, permeating through deeper faults, was probably responsible for the gold transport and its subsequent deposition in an evaporitic repository of carbonates and quartzofeldspathic rocks. In sharp contrast, recent studies on geological characteristics of this prospect have suggested a magmatic hydrothermal process of genesis, with gold concentration taking place during regional metamorphism (Deol et al. 2010, 2012).

\section{Deformation and metamorphism of host rocks in the mineralised zone}

Deformation and metamorphism of the ores and the host rocks have been elucidated in this section at the outcrop and the microscopic scale. The effects of deformation are best manifested as penetrative foliations (e.g., $\mathrm{S}_{1}$ and $\mathrm{S}_{2}$ schistosity) in micaceous rocks, whereas the marble units lack any 


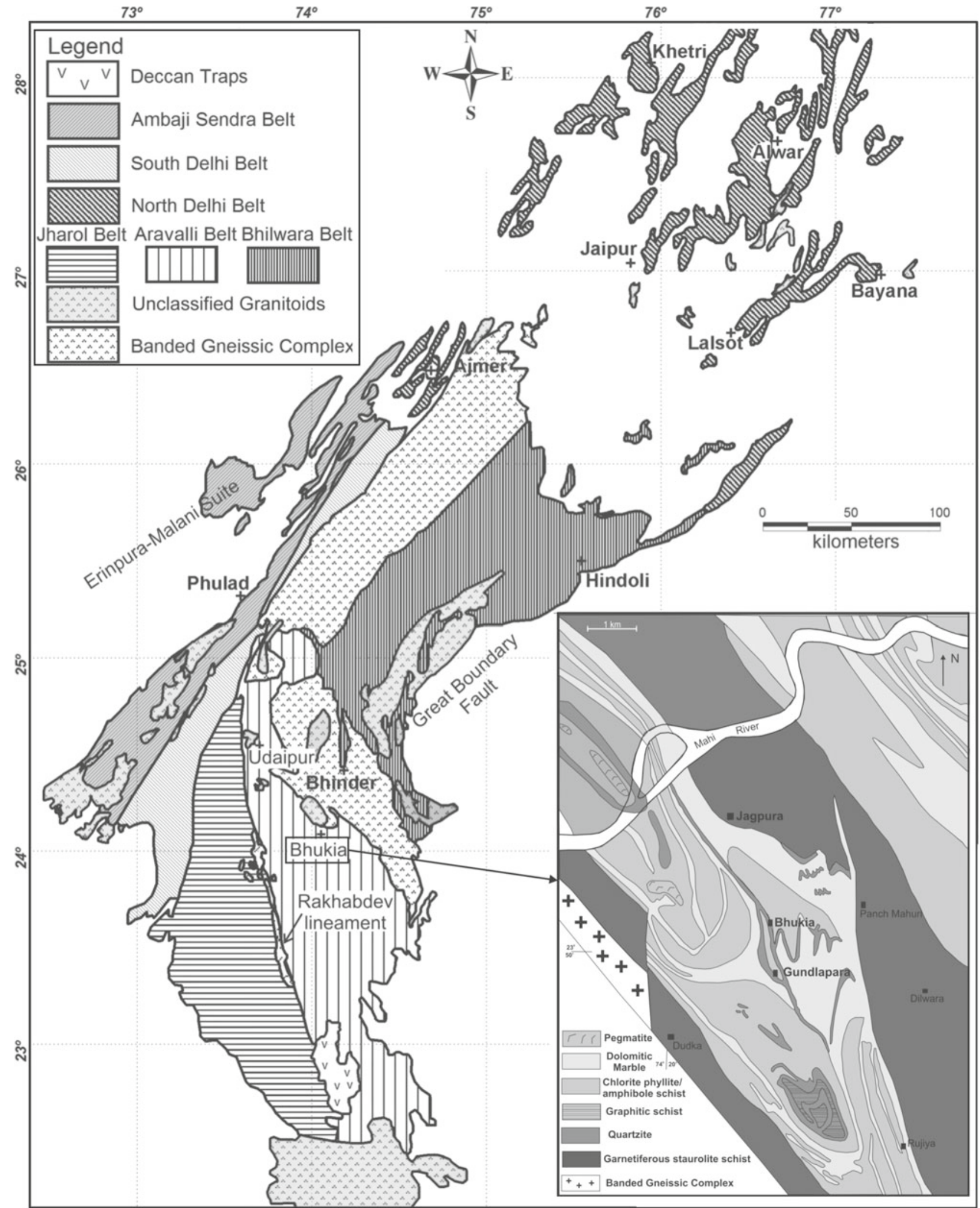

Figure 1. Geological map of the Aravalli-Delhi orogenic belt (modified after Heron 1953 and Deb and Sarkar 1990). Inset shows geological map of Bhukia-Jagpura area, southeastern Rajasthan (modified after GSI 1994).

prominent foliation and show pervasive annealing and recrystallisation. However, superposed folds on silicate layers in impure marble units, reflect the effect of polyphase deformation on these rocks. The earliest deformation $\mathrm{D}_{1}$ resulted in tight to isoclinal, and commonly reclined $\mathrm{F}_{1}$ folds at the 


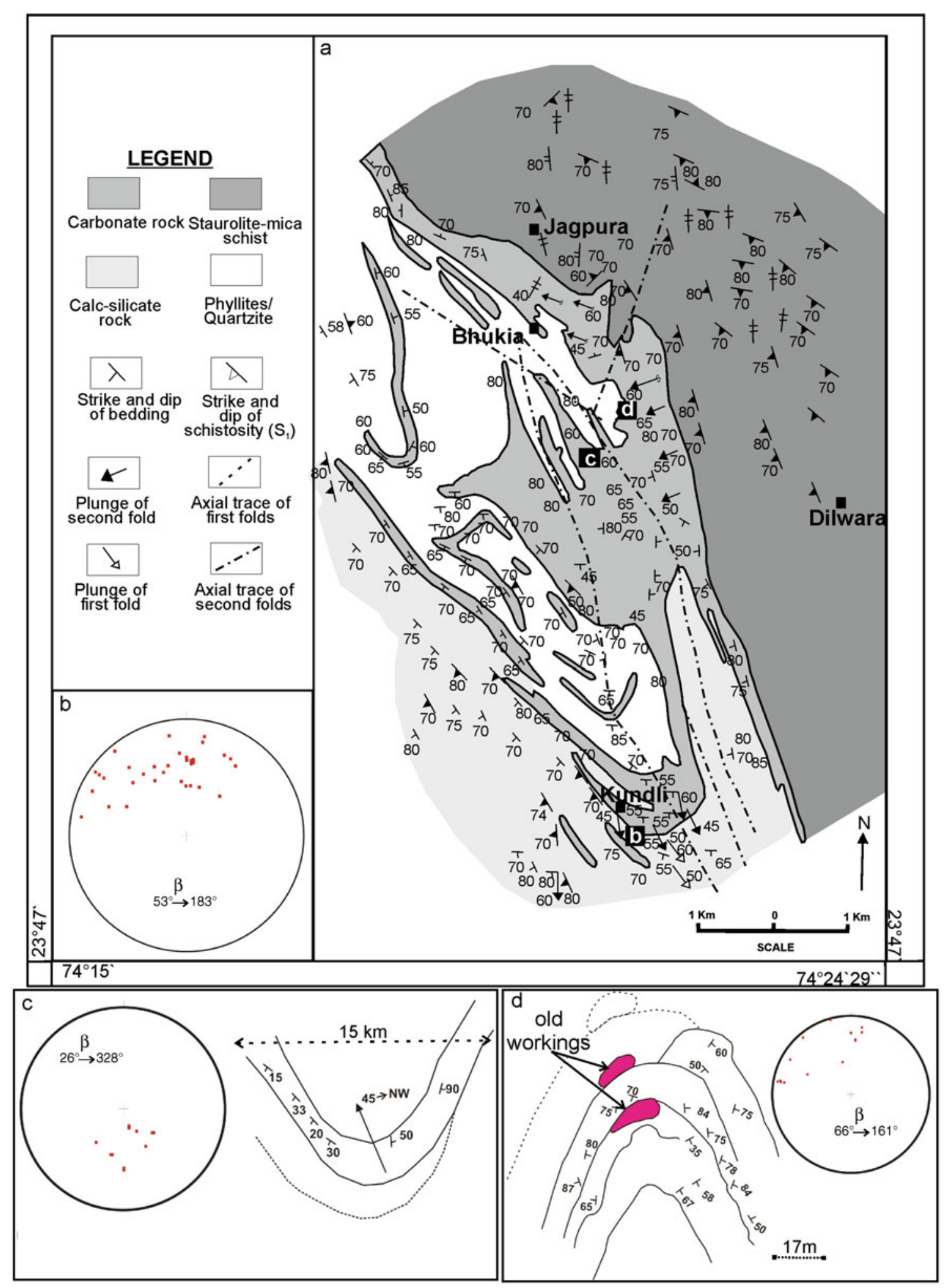

Figure 2. (a) Structural map of Bhukia and its adjoining area (modified after Sengupta 1976). A stereographic projection showing bedding plane poles of the $\mathrm{F}_{2}$ folds from (b) Kundli and (c) Gundlapara. (d) The stereonet plots of the data collected from the old workings along with their sketches; old workings are mainly located within intercalated carbonate rock/calc-silicate rock and quartzite.

outcrop scale (figure 3a). As the $\mathrm{F}_{1}$ folds are isoclinal, the $\mathrm{S}_{1}$ schistosity is generally parallel to bedding $\left(\mathrm{S}_{0}\right)$ except at the $\mathrm{F}_{1}$ hinges. $\mathrm{F}_{1}$ has a variable orientation due to reorientation by large scale $\mathrm{F}_{2}$ folding. The second generation folds $\left(\mathrm{F}_{2}\right)$ are upright to steeply inclined (figure $3 \mathrm{~b}$ ) and show 

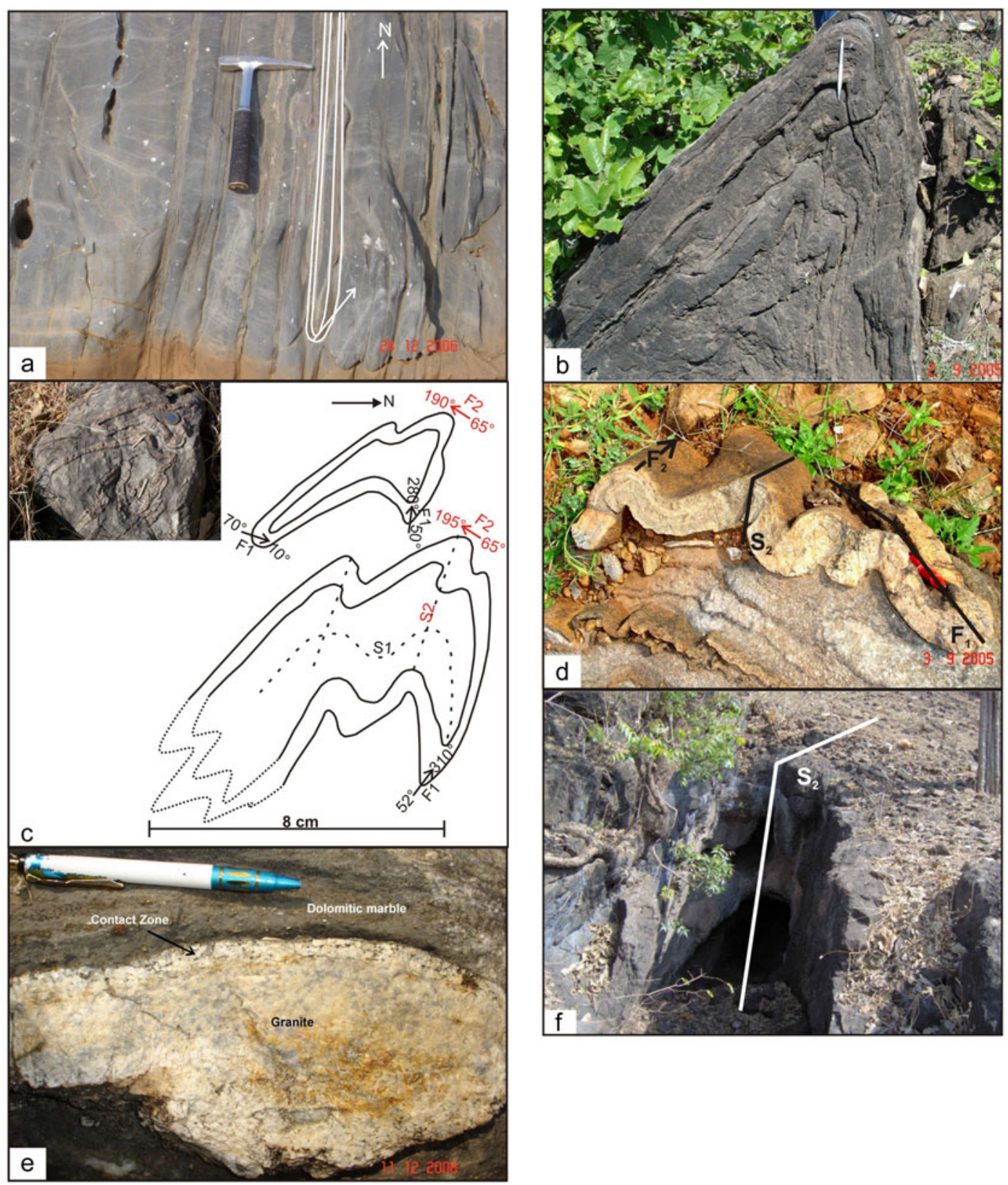

Figure 3. Field photographs of $(\mathbf{a})$ isoclinal $\mathrm{F}_{1}$ folds in calc-silicate rock. (b) Steeply inclined $\mathrm{F}_{2}$ fold. (c) Type II interference of $F_{1}$ and $F_{2}$ folds. The smaller fold (top of the photograph) is a boomerang-shaped interference pattern. The larger fold is also a boomerang with one side eroded out. (d) Type III hook-shaped interference of $\mathrm{F}_{1}$ and $\mathrm{F}_{2}$ folds. (e) Chilled margins at the contact of carbonate rock and granite comprising altered minerals parallel to the margin (near Bhukia-Ghatol road crossing). (f) A large old working subparallel to the $\mathrm{F}_{2}$ axial plane.

moderate to steep plunge $\left(50^{\circ}-75^{\circ}\right)$ towards NNW or SSE. These folds are disharmonic in nature and are locally polyclinal, which is more common in impure laminated marble with high competency contrast between the layers (figure $3 \mathrm{~b}$ ). $\mathrm{F}_{2}$ folds are commonly associated with silicification. $\mathrm{F}_{3}$ folds are represented by open warps oriented at a high angle with $\mathrm{F}_{2}$ axial planes. A set of widely spaced pressure-solution bands occur parallel to the $\mathrm{F}_{3}$ axial planes at outcrop scale.

Excellent examples of superposed folding are observed in outcrops of dolomitic marble, west of
Bhukia. The competent silica-rich layers within carbonate matrix are deformed by both $\mathrm{F}_{1}$ and $\mathrm{F}_{2}$ folds and this resulted in Type II and Type III interference patterns (Ramsay and Huber 1987) depending on the local orientation of $\mathrm{F}_{1}$ folds. Non-coaxial, non-coplanar overprinting of $\mathrm{F}_{2}$ folds over $\mathrm{F}_{1}$ folds leads to a non-planar, non-cylindrical (Type II) interference pattern, whereas coaxial, non-coplanar interference results in cylindrical non-planar (Type III) interference folds. The Type II superposition ( $c f$. Ramsay and Huber 1987) forms mushroom-shaped or 

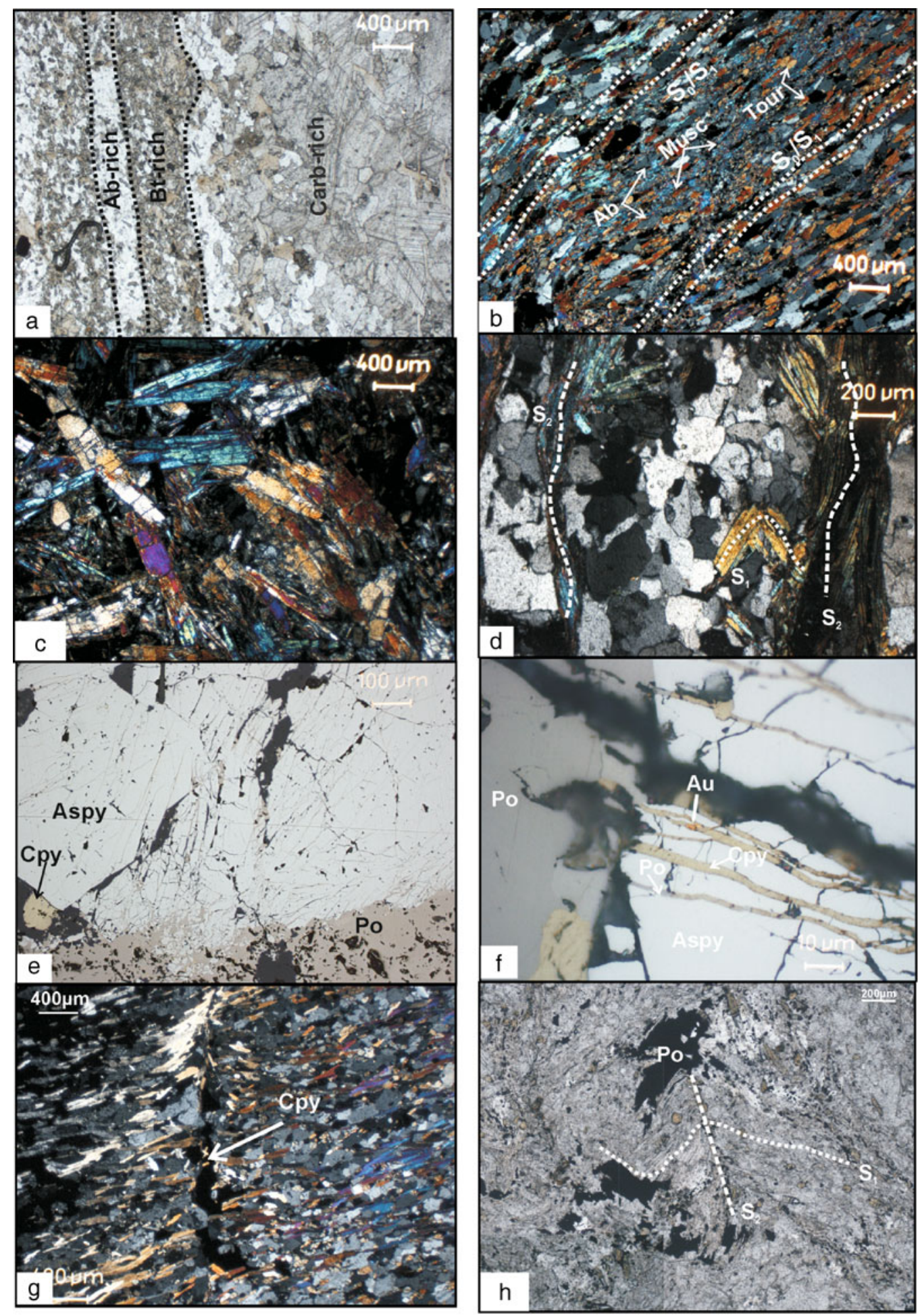

Figure 4. Photomicrographs showing: (a) alternate parallel bands (parallel to $\mathrm{S}_{0} / \mathrm{S}_{1}$ surfaces) of carbonate-rich, albite-rich and biotite-rich layers in a highly altered carbonate rock (under transmitted light). (b) Flattened grains of albite, muscovite, tourmaline, quartz and fine opaque grains displaying $\mathrm{S}_{1}$ schistosity (under transmitted light). (c) Tremolite-rich rock showing blade-shaped grains of tremolite arranged in an irregular manner (under transmitted light). (d) Spaced foliation, where quartzofeldspathic mass (microlithons) alternates with the phyllosilicates (crenulation cleavage). Relict folding (on $\mathrm{S}_{1}$ ) is present in between the parallel layers of phyllosilicates $\left(\mathrm{S}_{2}\right)$. Folding of $\mathrm{S}_{2}$ during third phase of folding is seen as broad warps (under transmitted light). (e) Subhedral to anhedral coarse porphyroblasts of highly fractured arsenopyrite within a mass of pyrrhotite. Fractures in arsenopyrite are filled up by pyrrhotite (under reflected light). (f) Thin veins comprising chalcopyrite and pyrrhotite within highly fractured and deformed grain of arsenopyrite. Fine grain of gold $(\sim 2.5 \mu \mathrm{m})$ is present, within the veins, in association with chalcopyrite (under reflected light). (g) Remobilisation of chalcopyrite along $\mathrm{F}_{2}$ fold axis in a quartz-albite rock (under transmitted light). (h) Remobilisation of pyrrhotite mass along the hinges and axes of $\mathrm{F}_{2}$ micro-folds in a tourmaline-bearing rock (under transmitted light). 
boomerang-shaped outcrop pattern (figure 3c), in which both the hinge line and the axial surface of $\mathrm{F}_{1}$ folds are curved. In Type III hook-shaped interference pattern, the hinge lines of $F_{1}$ and $F_{2}$ folds are straight and parallel, but the axial surface $\left(\mathrm{S}_{1}\right)$ is curved/folded (figure $3 \mathrm{~d}$ ).

Regional structural mapping was beyond the scope of the present study. However, different structural features (e.g., fold axis, bedding, cleavage) measured during regional traverses in the study area are consistent with that of the regional fold patterns described by earlier researchers such as Sengupta (1976). The bedding plane $\left(\mathrm{S}_{0} / \mathrm{S}_{1}\right)$ poles for Kundli hill, lying south of Bhukia, fall on a somewhat diffused girdle, showing a best-fit $\beta$-axis plunge of $53^{\circ} \rightarrow 189^{\circ}$ for the large scale $\left(\mathrm{F}_{2}\right)$ folds (figure $2 \mathrm{~b}$ ). Stereo-net plots of bedding/cleavage data of $\mathrm{F}_{2}$ folds from the northern part of Bhukia show a southerly plunge of the $\mathrm{F}_{2}$ axis (figure $2 \mathrm{~d}$ ), while $\mathrm{F}_{2}$ folds from Gundlapara show northerly axial plunge (figure 2c). These variations of $\mathrm{F}_{2}$ fold axes on regional scale indicate large scale noncylindrical nature of $\mathrm{F}_{2}$ folds, consistent with the observations of Garhia et al. (2001). It may be noted here that $\mathrm{F}_{2}$ folds are non-cylindrical in outcrop scale also, mainly due to superposition of open $\mathrm{F}_{3}$ folds over $\mathrm{F}_{2}$.

Geothermobarometric calculations using metapelitic mineral assemblage of garnet + biotite + muscovite + plagioclase + chlorite + quartz, (defining $\mathrm{S}_{1}$ fabric) indicate that peak metamorphism was synchronous with the first phase of deformation $\left(\mathrm{D}_{1}\right)$ at $\sim 500^{\circ} \mathrm{C}$ and $5.3 \mathrm{~kb}$, suggesting amphibolite facies regional metamorphism (see Deol et al. 2010 for details). Multi-equilibrium geothermobarometry of the late cross cutting calcite veins, associated with Ca-amphibole, chlorite, biotite, plagioclase, talc and sulphides (pyrite, pyrrhotite and arsenopyrite), gave $\mathrm{P}-\mathrm{T}$ estimates of $470^{\circ} \mathrm{C}$ and $3.2 \mathrm{~kb}$ and represent late stage retrogression with hydrothermal activity (Deol 2010). In the absence of an unambiguous textural relationship between $\mathrm{D}_{2}$ and the retrograde metamorphic mineral assemblage, it can only be suggested that $\mathrm{D}_{2}$ post-dated the regional peak (syn- $\left.\mathrm{D}_{1}\right)$, metamorphism and occurred on its retrograde metamorphic path.

\section{Nature of hydrothermal alteration and gold-sulphide mineralisation}

Carbonate-rich rocks, calc-silicate-, albite- and tourmaline-bearing rocks are the most common host rocks for gold-sulphide mineralisation in Bhukia-Jagpura prospect, which are gradational with each other at all scales (Deol et al. 2010). The whole metasedimentary sequence is intruded by a number of synkinematic pegmatite and granite bodies often present along the $\mathrm{S}_{1}$ schistosity (figure 3e).

Protoliths of the host rocks were affected by hydrothermal alteration, represented by multiple phases of Na-, B- and Si-metasomatism. The presence of cross cutting veins of tourmaline and albite in tourmaline-bearing quartz-albite rocks, and alternate bands of very fine and fine albite grains in albite-rich rocks suggests the possibility of more than one phase of albitisation and tourmalinitisation. Albitisation of the host rocks is ubiquitous, which is also seen in the clastic country rocks, such as in the metapelites. The alteration minerals, such as calcic-amphibole, phlogopite, muscovite, chlorite, secondary calcite, epidote, allanite, titanite, and flattened albite, tourmaline as well as ilmenite and rare magnetite, are arranged parallel to $\mathrm{S}_{0} / \mathrm{S}_{1}$ surfaces (figure $4 \mathrm{a}$ and $\mathrm{b}$ ). This style of alteration often shows sharp contact, varying from $\mu \mathrm{m}$ to $\mathrm{cm}$ scale, and is associated with scanty silicification. However, at places, these alteration bands do not maintain parallelism and show undulatory and diffused contacts. Radiating to irregular, decussate arrangement of graphite, muscovite and calcic-amphiboles represent relict signature of a thermal effect, possibly due to the granitic intrusion in the area. These domains are not overprinted by otherwise pervasive $S_{1}$ schistosity (figure $4 \mathrm{c}$ ).

In borehole samples, four styles of mineralisation were identified: (1) patchy/stringery, (2) banded, (3) vein, and (4) massive type. Patchy/stringery type mineralisation (figure $5 \mathrm{~b}$ ) contains irregular masses of pyrrhotite, arsenopyrite, and rare chalcopyrite within albite-bearing calc-silicate rocks. Banded type mineralisation (figure $5 \mathrm{a}$ ) is present as fine to medium alternating bands of pyrrhotite or arsenopyrite within calc-silicate or tourmalinerich host rocks. It is also associated with hydrothermal alteration parallel to the $\mathrm{S}_{1}$-surface in the carbonate host rocks, showing fine parallel bands of calc-silicate minerals. Vein type mineralisation (figure 5c) includes veins of fine- to medium-grained quartz and sulphides (pyrrhotite) that cut the host rock fabric at a high angle. Massive type mineralisation (figure 5d) contains greater than $60 \%$ sulphides represented by pyrrhotite, chalcopyrite, and coarse-grained arsenopyrite, with coarse to medium grained patches of quartz and various host rock fragments.

\section{Deformation and metamorphism in the ore zone}

Due to the paucity of exposed ore bodies and absence of proper mine face in the area, the old workings have been used to deduce the 

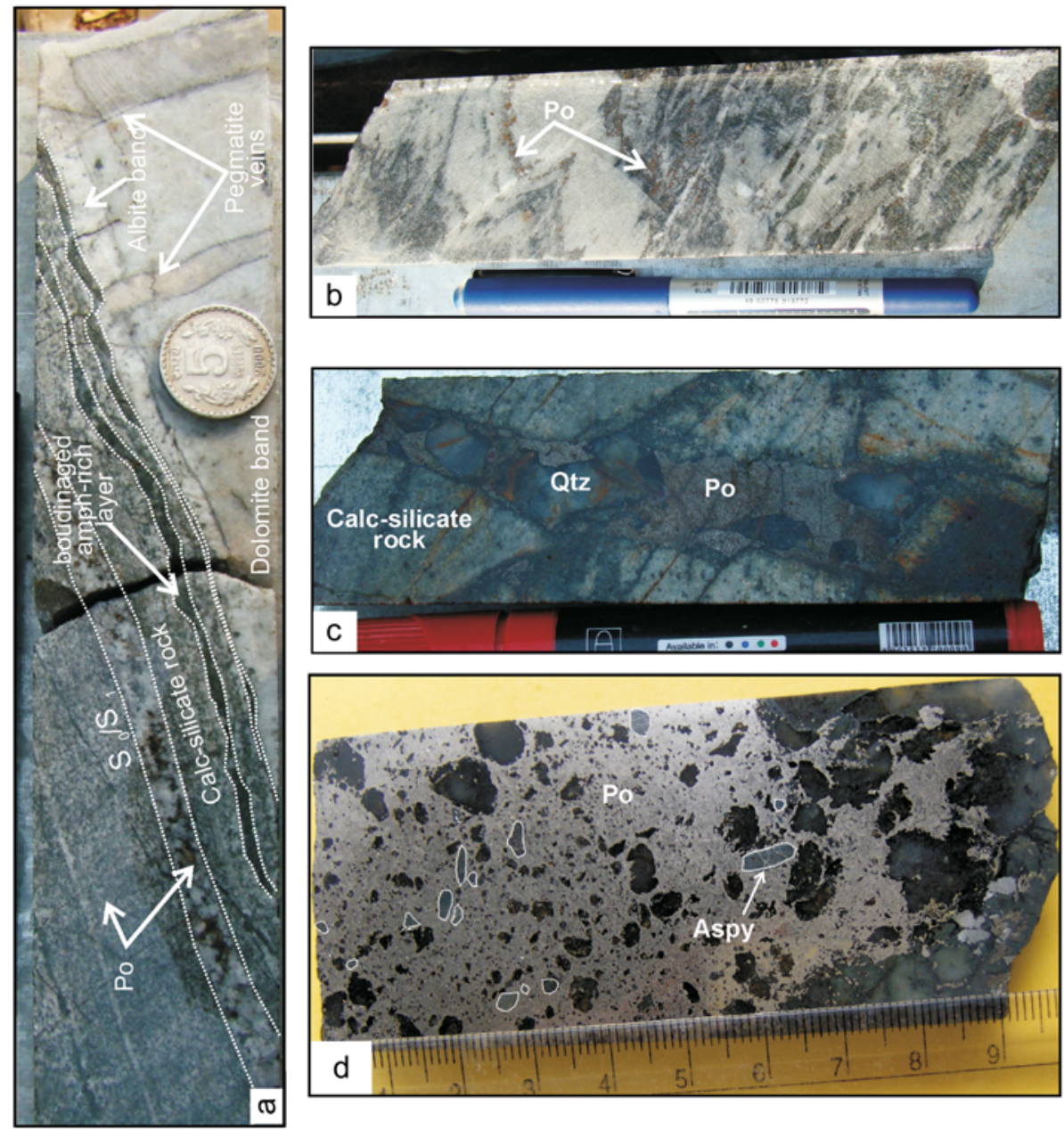

Figure 5. Borehole samples showing (a) sharp contact of calc-silicate rock and dolomitic marble; at the contact boudinaged amphibole-rich layer can be seen. Pyrrhotite, within calc-silicate rock and albite veins, is present parallel to $\mathrm{S}_{0} / \mathrm{S}_{1}$ surfaces. (b) Patches of pyrrhotite and calc-silicate minerals within dolomitic marble. (c) Vein of quartz, along with pyrrhotite, cross cutting the calc-silicate rock. (d) Rounded and ellipsoidal grains of arsenopyrite in association with rounded patches of host rocks in massive pyrrhotite showing durchbewegt texture.

3-dimensional disposition of the mineralised zones and its relation with the structures. About 50 old workings and prospecting pits are reported within a $6 \mathrm{~km}^{2}$ area around Bhukia village (Grover and Verma 1993), covering all the three potential prospects, Bhukia, Jagpura and Gundlapara. On a regional scale, the old workings generally follow a NNW-SSE trending linear pattern on the map, parallel to the axial traces of the $\mathrm{F}_{2}$ folds (figure 6). On a transverse section, these old workings appear to have been dug along the axial planes of $\mathrm{F}_{2}$ folds plunging either to the NNW or SSE. This is highlighted in an ENE-WSW oriented geological section (figure 7), where the ore bodies appear irregular, lensoid and subparallel to the $\mathrm{S}_{2}$ (striking $\mathrm{N}-\mathrm{S}$ ) with the largest ore body having a surface expression in a large old working, about $70 \mathrm{~m}$ in length and $10 \mathrm{~m}$ in width (figure $3 \mathrm{f}$ ). A set of circular to elliptical shaped old workings have also been observed at the hinge zone of $\mathrm{F}_{2}$ folds especially along the contact of calc-silicate and quartzite litho units (figure 2d). These observations suggest that in 3-dimension, these old workings are parallel to the axial plane $\left(\mathrm{S}_{2}\right)$ and are possibly elongated parallel to $\mathrm{F}_{2}$ fold axis.

Mesoscopic and microscopic observations from drill core samples reveal the imprints of $D_{1}$ and $D_{2}$ on the host rocks and associated Au-bearing sulphides. The patchy/stringery and banded types of mineralisation, discussed above, are stratiform and are accompanied by hydrothermal alteration parallel to $\mathrm{S}_{0} / \mathrm{S}_{1}$ surfaces. Silicification is rarely observed in these stratiform ores. In contrast, the vein and massive type mineralisation occur as medium to coarse-grained sulphides transecting the $\mathrm{S}_{0} / \mathrm{S}_{1}$ surfaces and are mainly associated with the large scale silicification. The last two styles of mineralisation are often associated with brecciation, where mineralisation is present within the intergranular spaces of brecciated clasts. Rounded and ellipsoidal 


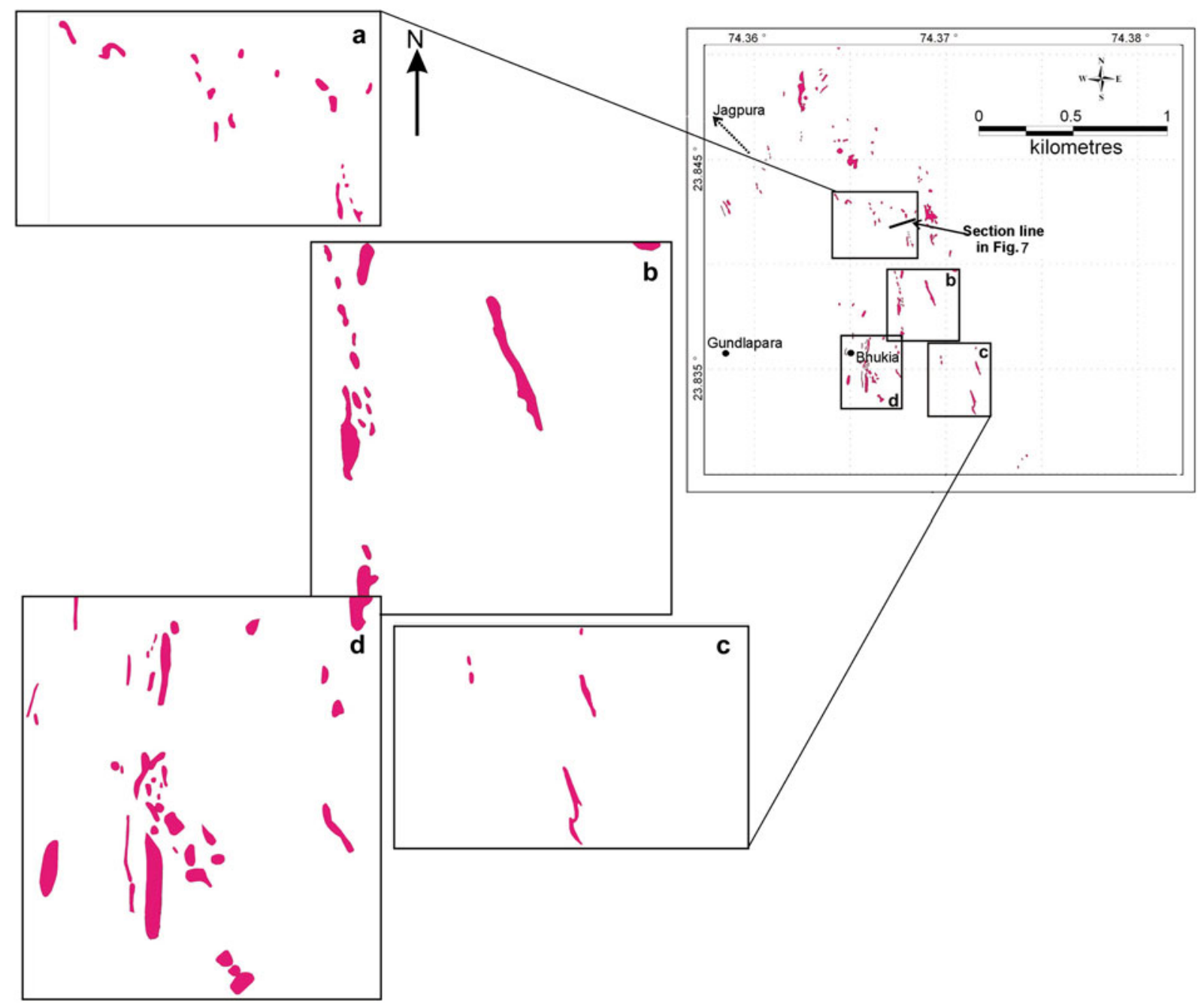

Figure 6. Plan view of some of the old workings in Bhukia mineralised zone (after Metal Mining India Ltd.).

grains of arsenopyrite along with rounded patches of rolled host rocks in massive pyrrhotite mass (figure 5d) define a 'durchbeweget' texture (Vokes 1969).

Under the microscope, the schistose metapelitic rocks display well-developed spaced cleavage $\left(\mathrm{S}_{2}\right)$, where unfoliated microlithons (quartz and plagioclase) alternate with strong cleavage domains (muscovite + chlorite). Relict microfolds, representing folded $\mathrm{S}_{1}$ schistosity, are present in the microlithons of $\mathrm{S}_{2}$ confirming $\mathrm{S}_{2}$ is a second generation crenulation cleavage. Weak folding of $\mathrm{S}_{2}$ indicates the imprints of later $\mathrm{D}_{3}$ deformation (figure 4d). Parallel bands of sulphides, viz., arsenopyrite, pyrrhotite and chalcopyrite; oxides, viz., ilmenite, magnetite and titanite alongwith silicates and carbonates suggest hydrothermal alteration and concomitant stratiform mineralisation parallel to $\mathrm{S}_{0} / \mathrm{S}_{1}$ (figure $4 \mathrm{a}$ and $\mathrm{b}$ ).

The discordant style of mineralisation (veinand massive-types) exhibits deformation, recrystallisation and coarsening of the sulphides and the associated silicate and carbonate minerals. The deformation-induced recrystallisation resulted in coarsening and grain growth of arsenopyrite, pyrrhotite and chalcopyrite, and also caused development of triple junction points in pyrrhotite. Due to continued deformation, the recrystallised coarse grained arsenopyrites were affected by brittle fracturing and protoclastic granulation along the margins (figure 4e). However, the softer minerals like pyrrhotite and chalcopyrite showed ductile behaviour during deformation, relocating themselves within the fractures in arsenopyrite (figure 4e), thereby manifesting contrasting deformation behaviour due to rheological difference. Such highly fractured coarse grains of arsenopyrite and the development of deformation lamellae in the subgrains of pyrrhotite suggest that the deformation outlasted grain growth and recrystallisation.

Gold is present as fine grains either as inclusions within coarse grains of arsenopyrite or within the fractures of arsenopyrite, in association with pyrrhotite and chalcopyrite (figure 4f). Within 


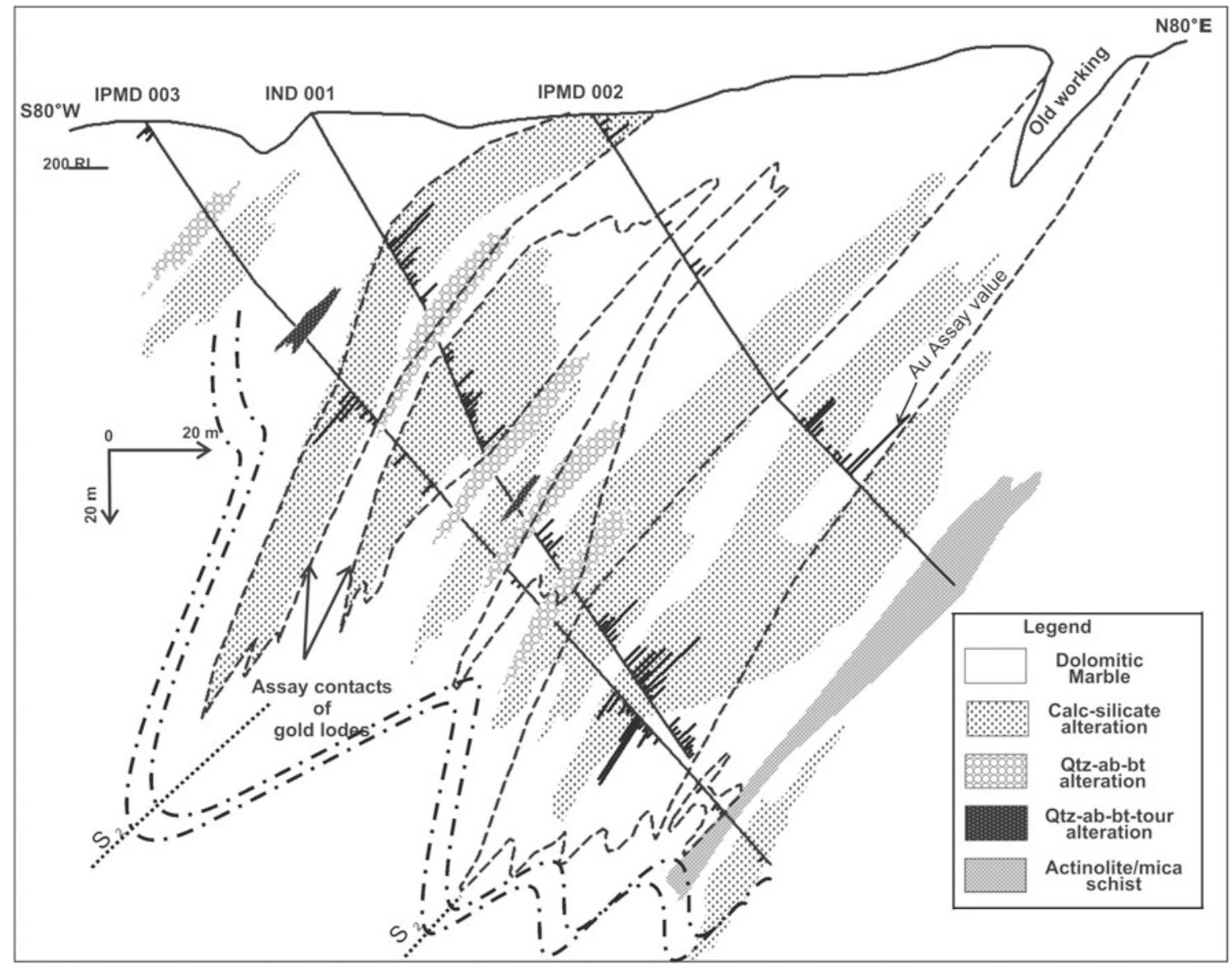

Figure 7. Transverse section showing the disposition of ore bodies at depth, subparallel to the trend of the $\mathrm{F}_{2}$ fold axis. Dashed/dotted lines indicate conjectured orientation of the regional $\mathrm{F}_{2}$ folds.

arsenopyrite, gold is often found as inclusions along with loellingite, pyrrhotite, wehrlite (Bi-Te alloy), and maldonite (Au-Bi alloy) (Deol et al. 2012). Pyrrhotite/chalcopyrite is also seen along the axial planes (figure $4 \mathrm{~g}$ ) and at the hinge zones of $\mathrm{F}_{2}$ micro-folds (figure $4 \mathrm{~h}$ ), further confirming the remobilisation of the sulphides during $\mathrm{D}_{2}$.

In the studied samples of the Bhukia-Jagpura prospect, invisible gold is identified by LA-ICPMS only in pyrites with low $\mathrm{Ni}$ :Co ratio $(\mathrm{Ni}: \mathrm{Co}<1)$, and in Co-rich arsenopyrites and loellingite (Deol et al. 2012). This trace element signature precludes the possibility of these Au-bearing pyrites being sedimentary-diagenetic in origin (LoftusHills and Solomon 1967; Mookherjee and Philip 1979). In contrast, sedimentary-diagenetic pyrites $(\mathrm{Ni}: \mathrm{Co}>1)$ are very rarely observed in these samples and they are completely devoid of invisible gold. This strongly supports the idea that the $\mathrm{Au}$-mineralisation in Bhukia-Jagpura area is epigenetic hydrothermal and not syn-genetic in nature.

On the basis of association and mineral chemistry, two different varieties of arsenopyrite (I and II) have been identified: arsenopyrite-I as inclusions within loellingite, rimmed by pyrrhotite, representing the prograde metamorphic assemblage (cf. Tomkins and Mavrogenes 2001), and arsenopyrite-II forming a reaction rim surrounding loellingite, in turn rimmed by pyrrhotite, characteristic of the retrograde metamorphic assemblage (cf. Neumayr et al. 1993). Using arsenopyrite thermometry (formulations of Kretschmar and Scott 1976; Sharp et al. 1985), the temperature obtained from the prograde assemblage ranges between $550^{\circ}$ and $530^{\circ} \mathrm{C}$, whereas the retrograde assemblage yields temperature range between $460^{\circ}$ and $474^{\circ} \mathrm{C}$ (Deol et al. 2012).

Thus it can be suggested that patchy and banded styles of mineralisation accompanying hydrothermal alteration in the host rocks occurred by fluid ingress along pervasive $S_{1}$ schistosity during early syn- $\mathrm{D}_{1}$ phase. The metamorphic fabric and the peak metamorphic temperature obtained from the ores $\left(490^{\circ}-570^{\circ} \mathrm{C}\right)$, which is comparable to those obtained from silicate thermometry of the host rocks $\left(\sim 500^{\circ} \mathrm{C}\right.$ at $\left.5.3 \mathrm{~kb}\right)$, indicate that the ore and the host rocks were isofacially metamorphosed during $\mathrm{D}_{1}$ at amphibolite facies conditions.

Massive and vein type mineralisation, on the other hand, are mainly associated with large scale 
silicification discordant to $\mathrm{S}_{0} / \mathrm{S}_{1}$ fabric and parallel to $\mathrm{S}_{2}$ indicating their syn- $\mathrm{D}_{2}$ development. Presence of sulphides within the fractures of arsenopyrite and intergranular spaces of silicate and carbonate minerals, and along axial traces and hinge zones of $\mathrm{F}_{2}$ crenulations in microscopic scales is suggestive of remobilisation of the ore during this phase. The occurrence of fine gold grains within the fractures of arsenopyrite healed by pyrrhotite and chalcopyrite possibly suggests the extraction of the metal from arsenopyrite host and its subsequent remobilisation with the ductile sulphides during $\mathrm{D}_{2}$. Old workings in the area also strike parallel to the axial trace of the $\mathrm{F}_{2}$ folds and are elongated along their hinge zones. The mineralisation is not specific to any lithological type and is observed along the lithological contacts suggesting that these contacts have acted as favourable conduits for the mobilisation/remobilisation of the ore fluid. The retrograde $\mathrm{P}-\mathrm{T}$ condition of the host rocks is estimated at $\sim 470^{\circ} \mathrm{C}, 3.2 \mathrm{~kb}$ and retrograde temperatures for ores range between 460 and $474^{\circ} \mathrm{C}$. It needs to be mentioned that the exact position of $\mathrm{D}_{2}$ on the metamorphic retrograde path cannot be constrained due to the lack of retrograde textures in silicates. The lowest retrograde metamorphic temperature of the ores can be further traced to $241^{\circ} \mathrm{C}$ and to $\sim 116^{\circ} \mathrm{C}$ (Deol et al. 2012).

\section{Discussion}

Although the Bhukia-Jagpura gold-sulphide prospect has been the subject of research by various researchers, the ore genetic study has not been dealt with a holistic approach. So far, the relationship between ore and host rocks, the extent and effect of metamorphism in the area, the role of structure in the formation/transformation of ore, timing of ore emplacement vis-à-vis deformation and metamorphism, etc., are not clearly established. In this respect, the relationship between regional deformation, metamorphism and goldsulphide mineralisation in Bhukia-Jagpura area has been established in the present study from the spatial distribution of mineralised zones with respect to the macroscopic, mesoscopic and microscopic structural patterns, as described above.

Compiling all the observations documented in this paper, it is suggested that gold-sulphide mineralisation in Bhukia-Jagpura area is emplaced by structurally controlled epigenetic processes. The gold-bearing sulphides accompanying hydrothermal alteration formed parallel to $S_{1}$ during the first deformation $\left(\mathrm{D}_{1}\right)$. The sulphides, silicates and carbonates underwent isofacial regional metamorphism under amphibolite facies conditions during $\mathrm{D}_{1}$ (figure 8a). The $\mathrm{S}_{0} / \mathrm{S}_{1}$ parallel arrangement of alteration minerals, such as calcic-amphiboles, biotite, muscovite, and flattened albite and tourmaline, confirms that alteration is early syn- $\mathrm{D}_{1}$ and did not post-date the $\mathrm{D}_{1}$ metamorphism. The presence of calcic-amphiboles and albite, showing enhancement of An component (up to 11\%) (Deol 2010), suggests that the alteration assemblage was stable at the $\mathrm{P}-\mathrm{T}$ conditions of $\mathrm{D}_{1}$ metamorphism under amphibolite facies.

The syn- $\mathrm{D}_{1}$ granite intrusion possibly acted as a local heat source for hydrothermal fluid circulation. The decussate texture of graphite, muscovite and

(A) Peak phase of metamorphism- syn- $D_{1}$

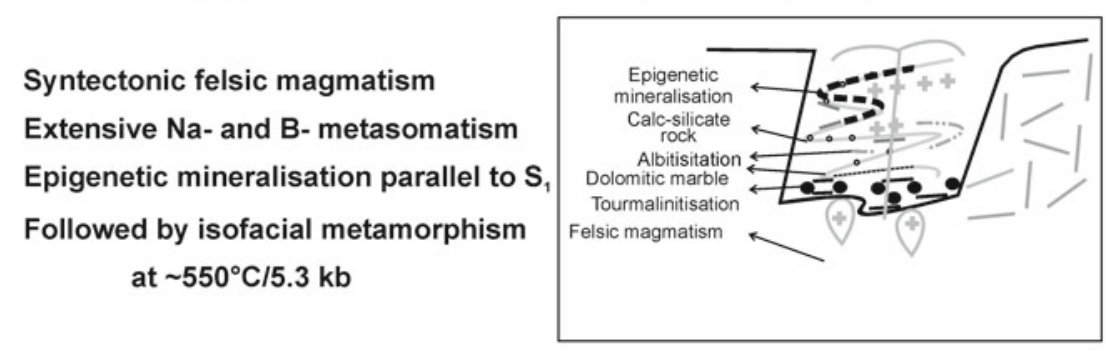

(B) Retrograde phase of metamorphism- syn- $D_{2}$ ?

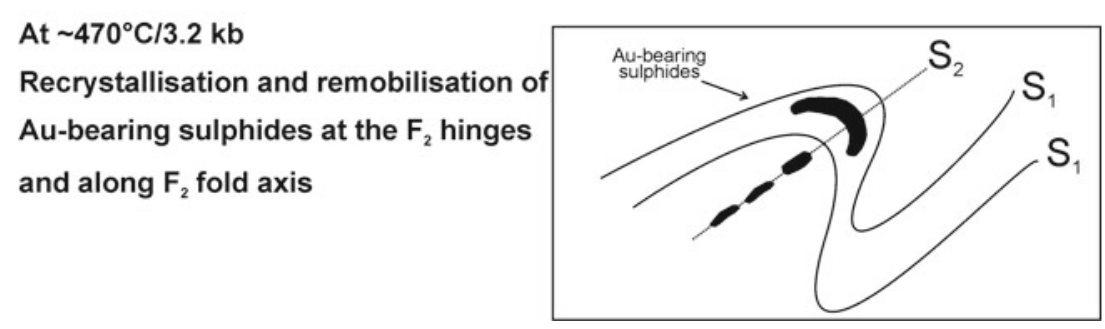

Figure 8. Cartoon showing relationship of mineralisation with different phases of deformation and associated metamorphism. 
calcic-amphiboles are not overprinted by otherwise pervasive $S_{1}$ schistosity (figure $4 \mathrm{c}$ ). This indicates that thermal effects from granite emplacement may have outlasted $\mathrm{D}_{1}$ deformation.

The sulphides were later remobilised and further concentrated during the subsequent phase of deformation $\left(D_{2}\right)$ at the hinges and along the axial planes of $\mathrm{F}_{2}$ folds (figure 8b). This is in contrast to the views of previous authors, such as Garhia et al. (2001), who suggested that mineralisation and associated hydrothermal alteration were synchronous with early to 'late $\mathrm{F}_{2}$-deformation', and Guha (2004), who negated the hydrothermal replacement hypothesis of metal genesis and its concentration.

The inferences regarding structural control of gold-sulphide mineralisation and their remobilisation, as brought in the present contribution, will be useful during future regional exploration and eventual exploitation of the prospect, and for the understanding of its genesis.

\section{Conclusions}

- Gold-sulphide mineralisation in the BhukiaJagpura is structurally controlled. Preferred orientation of sulphide grains and associated alteration along $\mathrm{S}_{0} / \mathrm{S}_{1}$ surfaces, presence of syntectonic granite (with respect to $\mathrm{D}_{1}$ ) and temperatures of $\sim 550^{\circ} \mathrm{C}$ calculated from the metamorphosed ore assemblages indicate that alteration related mineralisation, peak phase of metamorphism and granite intrusion are broadly early synchronous to $\mathrm{D}_{1}$, and not synchronous to $\mathrm{D}_{2}$ as suggested by some researchers previously.

- The gold-sulphide mineralisation was remobilised during subsequent $\mathrm{D}_{2}$-deformation and concentrated as silicified lodes at the hinge zones and along the axial planes of the $\mathrm{F}_{2}$ folds. These sites can be the favourable targets for the exploitation of ore in future.

\section{Acknowledgements}

The authors are grateful to the Department of Science and Technology (Deep Continental Studies Programme), Govt. of India for the grant of project funds. The authors thank Mr Surender Chaku, Metal Mining India Ltd., for facilitating the field work and for kindly providing access to the borehole samples, both of which form the essential components of the present study. The authors are also thankful to Mr Sanjeev Sharma, Metal Mining India Ltd., for informative field discussions.

\section{References}

Chattopadhyay A 2010 A review of the structural characteristics of orogenic gold deposits, with special reference to Indian gold fields; In: Gold Metallogeny - India and Beyond (eds) Deb M and Goldfarb R J (New Delhi: Narosa Publishing House), pp. 122-153.

Deb M and Sarkar S C 1990 Proterozoic tectonic evolution and metallogenesis in the Aravalli Delhi Orogenic belt, northwest India; Prec. Res. 46 115-137.

Deb M and Thorpe R I 2004 Geochronological constraints in the Precambrian geology of Rajasthan and their metallogenic implications; In: Sediment-hosted lead-zinc sulfide deposits with emphasis on the deposits in the northwestern Indian shield (eds) Deb M and Goodfellow W D (New Delhi: Narosa Publishing House), pp. 246-263.

Deol S 2010 Geological environment of gold-sulfide mineralization at Bhukia-Jagpura area, southern Rajasthan; Ph.D thesis, University of Delhi, India.

Deol S, Deb M and Chattopadhyay A 2010 Geology of the Bhukia-Jagpura Prospect, Banswara District, SE Rajasthan, India, and a model for gold mineralization; In: Gold Metallogeny - India and Beyond (eds) Deb M and Goldfarb R J (New Delhi: Narosa Publishing House), pp. 234-255.

Deol S, Deb M, Large R R and Gilbert S 2012 LA-ICPMS and EPMA studies of pyrite, arsenopyrite and loellingite from the Bhukia-Jagpura gold prospect, southern Rajasthan, India: Implications for ore genesis and gold remobilization; Chem. Geol. 326-327 72-87.

Garhia S S, Jat R L, Guha D B and Harpawat C L 2001 Hydrorthermal gold mineralization in the Bhukia gold prospect of the lower Proterozoic Aravalli fold belt of Rajasthan; Geol. Surv. India 58 375-384.

Geological Survey of India 1994 Mineral belt map of Bhukia gold area and its extension in Banswara, Dungarpur and Udaipur district, Rajasthan.

Golani P R, Rajawat R S, Pant N C and Rao M S 1999 Mineralogy of gold and associated alloys in sulfides of Bhukia gold prospect in southeastern Rajasthan, western India; J. Geol. Soc. India 54 121-128.

Golani P R, Pandit M K, Sial A, Fallick A E, Ferreira V P and Roy A B 2002 B-Na rich Paleoproterozoic Aravalli metsediments of evaporitic association, NW India: A new repository of gold mineralization; Prec. Res. 116 183-198.

Grover A K and Verma R G 1993 Gold mineralization in the Precambrians (Bhukia area) of southeastern Rajasthan-A new discovery; J. Geol. Soc. India 42 281-288.

Guha D B 2004 Ore petrography, mineralogy and localisation of sulphide-gold mineralization of East Central Block, Bhukia, Banswara District, Rajasthan; Geol. Surv. India 72 175-188.

Gupta B C 1934 The geology of central Mewar; Geol. Surv. India Memoir 65 107-168.

Heron A M 1953 Geology of Central Rajputana; Geol. Surv. India Memoir 79389.

Horne R and Culshaw N 2001 Flexural-slip folding in the Meguma Group, Nova Scotia, Canada; J. Struct. Geol. 23 1631-1652.

Kolb J, Rogers A, Meyer F M and Vennemann T 2004a Development of fluid conduits in the auriferous shear zones of the Hutti Gold Mine, Dharwar craton, India: Evidence for spatially and temporally heterogeneous fluid flow; Tectonophys. $\mathbf{3 7 8} 65-84$.

Kolb J, Hellmann A, Rogers A, Sindern S, Vennemann T, Böttcher M E and Meyer F M 2004b The role of a transcrustal shear zone in orogenic gold mineralization at the 
Ajjanahalli mine, Dharwar Craton, South India; Econ. Geol. 99 743-759.

Kolb J, Rogers A and Meyer F M 2005 Relative timing of deformation and two-stage gold mineralization at the Hutti mine, Dharwar craton, India; Miner. Deposita 40 $156-174$.

Kontak D J and Horne R J 2010 A multi-stage origin for the Meguma lode gold deposits, Nova Scotia, Canada: A possible global model for slate belt-hosted gold mineralization; In: Gold Metallogeny - India and Beyond (eds) Deb M and Goldfarb R J (New Delhi: Narosa Publishing House), pp. 58-82.

Kretschmar U and Scott S D 1976 Phase relations involving arsenopyrite in the system $\mathrm{Fe}-\mathrm{As}-\mathrm{S}$ and their application; The Can. Mineral 14 364-386.

Loftus-Hills G and Solomon M 1967 Cobalt, nickel and selenium in sulfides as indicators of ore genesis; Miner. Deposita 2 228-242.

Mookherjee A and Philip R 1979 Distribution of copper, cobalt and nickel in ores and host-rocks, Ingladhal, Karnataka, India; Miner. Deposita 14 33-55.

Neumayr P, Cabri L J, Groves D I, Mikucki E J and Jackman J A 1993 The mineralogical distribution of gold and relative timing of gold mineralization in two Archean settings of high metamorphic grade in Australia; Can. Mineral. 31 711-725.

Partington G A and Williams P J 2000 Proterozoic lode gold and (Iron)-Copper-Gold deposits: A comparison of Australian and global examples; In: Gold in 2000 (eds) Hagemann S G and Brown P E, Rev. Econ. Geol. 13 69-97.
Ramsay J G and Huber M I 1987 The techniques of modern structural geology, strain analysis; London Academic Press.

Robert F and Poulsen K H 2001 Vein formation and deformation in greenstone gold deposits; Society of Economic Geologists, Rev. Econ. Geol. 14 111-155.

Roy A B and Jakhar S R 2002 Geology of Rajasthan Precambrian to Recent; Jodhpur: Scientific Publishers.

Sengupta S 1976 Structures and stratigraphic relations of the Aravallis, south eastern Rajasthan; J. Geol. Soc. India 17 461-470.

Sharp Z D, Essene E J and Kelly W C 1985 A re-examination of the arsenopyrite geothermometer: Pressure considerations and applications to natural assemblages; The Can. Mineral. 23 517-534.

Sinha-Roy S 1996 Stratigraphic and tectonic controls of gold mineralization in the Aravalli Fold Belt, Banswara district, Rajasthan; In: Gold, GSI-NGRI, pp. 158-160.

Tomkins A G and Mavrogenes J A 2001 Redistribution of gold within arsenopyrite and Lo during Pro- and retrograde metamorphism. Application to timing of mineralization; Econ. Geol. 96 525-534.

Vokes F M 1969 A review of the metamorphism of sulfide deposits; Earth-Sci. Rev. 5 99-143.

Windh J 1995 Saddle reef and related gold mineralization, Hill End Gold Field, Australia: Evolution of an auriferous vein system during progressive deformation; Econ. Geol. $901764-1775$.

Ziauddin M and Ramachandra A V 1963 Tectonics of the Kolar Gold Field, Mysore state; Geol. Soc. India Memoir $168-79$. 